\title{
Dimensions of Literature and Journalism, History, Ideology and Culture
}

\author{
Mohammed Osman Abdul Wahab \\ Department of English, Faculty of Languages and Translation, King Khalid University, Abha, Kingdom of Saudi \\ Arabia \\ Mohammed Nurul Islam \\ Department of English, Faculty of Languages and Translation, King Khalid University, Abha, Kingdom of Saudi \\ Arabia \\ Nisar Ahmad Koka \\ Department of English, Faculty of Languages and Translation, King Khalid University, Abha, Kingdom of Saudi \\ Arabia
}

\begin{abstract}
Literature is a hugely loaded term that brings within its ambit a variety of concerns ranging from philosophy to journalism as there is almost a photo finish between what is construed as journalism and what is commonly and widely presumed literature. Adding interactive or writing multi-platform stories/literature/fiction is quickly becoming a new craft of publishing onto itself and a tool for writers to use. The media field could be very different in coming years---or it could still be just a bunch of promotional tietins. The dimensions of literature breach boundaries to conform to the possibilities of generating discourses on issues of humanitarian concerns. Hemingway, Dos Passos, Dickens and Thackeray came to the writing of fiction through journalism. Psychology and Philosophy have given the edges to literature as the likes of James Joyce, Joseph Conrad and Virginia Woolf. Journalism aided the growth of imperial culture and simultaneously provoking a debate between the East and West, between the Fascist and the Liberals and between the Diary of A young Girl and Tin Drum and again between what Bertolt Brecht did in Germany to stave off the last remains of Nazism though diced up in ruins. The difference lies in the manner of treating its shades and colors.
\end{abstract}

Index Terms - literature and journalism, journalism, definition of journalism, history and ideology, cultural criticism, new media studies, literature overview

\section{INTRODUCTION}

The dimensions of literature and the objectives of journalism have coalescence of the kind that testifies the close yet marginal distinction between the two. This paper will briefly examine the dimensions of literature and journalism through a comparative analysis between history, ideology and culture. One dimension i.e. history involves the study of coalescence or concussion between the literature and history and ideology. A second dimension involves the study of ideology and its relation with literature and journalism. The third dimension i.e. culture is a broad term and it covers the religion. Language, food and costumes. It also deals with the way the languages are spoken in particular community the way they wear the costumes and the way they cook or serve food. It also encompasses the collective belief or behavior of a community.

\section{LITERATURE AND JOURNALISM}

Literature in its broadcast sense is any written work, especially those considered of superior or lasting artistic merit. Literature is a hugely loaded term that brings within its ambit a variety of concerns ranging from philosophy to journalism as there is almost a photo finish between what is construed as journalism and what is commonly and widely presumed literature. While defining about the narrative of a literary works. Arendt (2007) says without even committing error of defining it the storytelling defines the meaning. Arendt (2007) Journalism is providing news about the milieu and the rest of the parts of the world to an audience. Journalism on the other hand though is new scentic arguably, but it intrudes unconsciously into the normally considered areas of literature. Academic definitions of both literature vis-à-vis journalism have overlapped time and again to further blur the perceptions that illustrate the profound rupture in the treatment of issues that inadvertently crisscrossed and obviated the traditional hangover of journalism carried forward by those who were primarily journals before switching sides to end up as a mélange of the two.

The dimensions of literature breach boundaries to conform to the possibilities of generating discourses on issues of humanitarian concerns. Reporters and anchors writing pompous prose in a political discourse carries the echoes of literary high faulting jumbled thoughts and the pedantry of expressions importing ideas from the literary streams to add 
the punches in the fickle and florid dialogues with polity. Journalism therefore is a divorced mistress of the authoritarian literature.

Dickens and Thackeray came to the writing of fiction through journalism and their writings echoed the erstwhile flair they had evolved while writing on the moods of the British mavericks controlling the humbled and petrified consciousness at a time when literature was ambling up to define what is said in journalism as an afterthought of literature. Hemingway, Dos Passos, Charles Dickens and Thackeray trained their guns on journalism with a shooting mouth to raise alarms in turbulent British and American societies with their razor sharp piercing satirical lamentations on the polity of their time. Thus the dimensions of literature are more apparent than the concealed journalistic babbling and the debate between the two is akin to that of two brothers raising a wall in a courtyard.

\section{LITERATURE : OLD ENGLISH LITERATURE AN OVERVIEW}

The firs epic poem in English literature is Beowulf. It is a story of about 3000 lines. Beowulf is about the king of Danes known as Hrothgar and a brave young man, Beowulf is from Sweden who goes to help the king Hrothgar. By the end of the poem Beowulf becomes the king and has to fight against a fire-breathing creature to defend his country. Although he kills the animal but gets badly wounded and succumbs to his injures at the end. The poem end with the tragic description of Beowulf's funeral fire. Following are the few lines of it with the paraphrase:

Alegdon tha tommmiddes maerne theodon

Healeth hiofende leofne

Ongunnon tha on beorge hael-rec astah

Sweart ofer swiothole swogende leg

Wope bewunden

The mourning soldiers laid the body of their chivalrous and brave prince in the middle. The men lit the greatest fire for the great prince on the top of the hill. It was a combination of the noise of fire and the cries of the mournful soldiers on the hill when the wood rose into black smoke in the sky. Some critics don't accept Beowulf as part of English literature since it can't be read or understood by a common English learner. Only those who have made special study of it can paraphrase and understand it. There are many other old English poems. Genesis A and Genesis B are among them.

Caedman and Cynewulf are among the old English poets. Cynewulf, it is said, wrote four poems, Juliana, The Fates of the Apostles, Christ, and Elene. However, it is not certainly known about the poets of the poems Andreas and Guthlac. Critics say these poems were also written by either both of them or by one of them.

The battleof Maldon is also one of the well known old English poems. This poem is about the battle which was fought against Danes in 991 and the poem was written after that. Here are a few lines of it with modern English translation.

Hige sceal the headra heorte the cenre

Mod seal the mare the ure mae gen lytlath

Her lith ure te a maeg gnornian

Se the nu fram this wigplegan wendan thenceth

The mind must be the firmer, the heart must be the braver, the courage must be the greater, as our strength grows less. Here lies our lord all cut to pieces, the good man on the ground. If anyone thinks now to turn away from this war-play, may he be unhappy for ever after.

'Widsith', 'Doer' and 'Beowulf' are referred as pre-Christian age poems or the Anglo-Saxon poems dealing with the pagan age. These poems were compiled some time between the eight and tenth century. These poems depict the picture of civilized society with barbaric spirit impregnated with moral sense.

According to critics the Old English prose came much later than the verse. King Alfred (849-901) translated a number of Latin books into Old English for his people to read and understand. He also worked to improve the education of his people. Aelefric was also on of the important writers of Old English prose. He wrote religious works like Homilies and Lives of Saints. His prose style is considered to be the best among the old English writers.

Middle English Literature: From Norman Conquest to Chaucer: It is difficult to define the beginning or end of a social age. Only a chronological study of major events of that era can vaguely decide the beginning or end of an era. Chaucer who lived to see the reigns of three kings of England was the first national poet of the country. Many of his poems are filled with romantic idealism. However, the depiction of a pleasure-loving Monk and roguish and greedy Friers and priests depict the shocking state of religion in the age of Chaucer.

Elizabethan Age: Although queen Elizabeth ruled between 1558 to 1603 but according to critics the Elizabethan age of literature started only in 1579. During the Elizabethan age learning to write poetry was a part of a nobleman's education. The poet who introduced the Elizabethan age was Edmund Spenser in 1579. He produced a poem 'The Shepherd's Calendar' in twelve books. The sonnets of Shakespeare were written between 1593 and 1600 . The chief literary glory of the great Elizabethan age was drama. Shakespeare's plays Hamlet and Macbeth are considered as some of the best tragedies ever written in the world literature. Even after the passage of hundreds of years the plays still hold our attention. The tragic heroes Hamlet and Macbeth keep our sympathy but the end is certain and unavoidable.

Charles II became king in 1660 and the change in literature was also as great as the change in the government. The tragic drama of this period was mainly based on the heroic plays where men played the role of brave protagonists and 
the women were projected as beautiful creatures. The plays were written in heroic couplets and the best example of it is John Dryden's work.

Literature during Second World War: Although the years of Second World War are not considered as distinguished period for literature but T.S. Eliot's Four Quartets, one of the masterpieces of the century, Can't be ignored. Apart from literature the general enthusiasm was towards the performing arts like music, theatre, ballet and painting

\section{DEFINITION OF JouRnALISM}

Journalism is basically disseminating information deemed by the disseminator to be in the public interest. A more complex definition of journalism is the act of speaking truth to power. Journalism is considered the fourth pillar of a civil society or a democratic nation. In a society where the affairs of the state are run on taxes collected from the public, there is a need for a group that will hold the government accountable for how that money is spent. This is where journalism and journalists come to the fore.

There is a famous saying, attributed to George Orwell, that "journalism is printing what someone else does not want printed - everything else is public relations." Journalism, plain and simple, means empowering people with relevant information concerning the events of the day, week or year. There is a certain element of immediacy to journalism, especially in the present era of social media. People are immediately informed of what is happening with a certain issue, a certain government, a certain controversy, or a certain scandal.

Journalism is related to history in the sense that historians collate information about things that have happened in the past. Journalism is also sometimes called "literature in a hurry" but this only pertains to the craft of the language, the craft of the written, or the spoken word. There is otherwise no similarity or no comparison between literature and journalism. Journalism is based purely on facts; it is a different matter to acknowledge that journalists sometimes twist facts to suit a given agenda.

On the other hand, literature is often pure fiction though it may have some connection with real events. Literature is essentially created from a writer's imagination.

In the past, journalism was difficult to practice because there were very few outlets for airing thoughts or publishing reports. That is no longer the case because of the arrival of social media along with the technology that has empowered pretty much everybody with a cellphone which has a camera and an Internet connection.

Everybody can be a journalist because he or she is passing on relevant information within his circle or to those who subscribe to their blogs or to their websites or to their podcasts. How committed one is to true journalism depends on the credibility that the person enjoys among his or her circle of followers.

Good journalists, good podcasters, and good bloggers will remain in business because of the credibility they enjoy for having done their job of relaying information truthfully, exactly and, most importantly, without either malice or an agenda.

Journalism is the safety valve in many societies because to be informed is to be empowered and that is what journalism does - it empowers people, with facts and figures, thus enabling them to speak truth to power.

\section{HISTORY AND IDEOLOGY}

Ideology is the science of ideas. The study of the origin of thoughts and nature. Philosophy is the study of the origin of once belief. Culture has great impact on ideology and philosophy. Ideology and philosophy have direct impact on once personality. Psychology and Philosophy have given the edges to literature as the likes of James Joyce, Joseph Conrad and Virginia Woolf were more inclined to unearth the psychological bases of the human thoughts in times of distress. Journalism too at times trespasses the bounds of propriety to usher in a prosaic yet reverberating phase of intellectual writings. History and sociology too are the wickedly brothers of literature separated by the discovery of domains as separate entities. The ideology confronting literature and journalism are not mooted into fashionable exhibition of phraseology and idioms though again journalism acts as the sister cousin of an arrogant brother.

\section{Cultural CRITICISM}

Culture is the arts and other manifestations of human intellectual achievement regarded collectively. While teaching the art of literary appreciation of a work of literature we teach students to question them in a meaningful way that changes their perspective.(Beck, McKeown, Hamilton, \& Kucan, 1997; Liang \& Dole, 2006) Culture is a common pursuit chased by the slogan shouting cultural critics like Edward Said, Gayatri Spivak, Antonio Gramsci, Roland Barthes, Jacques Derrida and Lacan. These critics referred to as cultural critics explored the dynamics of cultural study as an independent research area by exposing the dominant Western political authority in providing a foothold to is rather superficial, jingoistic and ultra nationalist literature that flourished through a long handle of imperial assertions. That apart journalism aided the growth of imperial culture and simultaneously provoking a debate between the East and West, between the Fascist and the Liberals and between the Diary of A young Girl and Tin Drum and again between what Bertolt Brecht did in Germany to stave off the last remains of Nazism though diced up in ruins. Literature, 
Journalism both study culture in their own inimitable ways but the modus operandi is rotated to distinguish the domains called by different names with a philosophy as common as the study of civilization and culture.

\section{NEW MEDIA STUdIES}

It is a new academic discipline. It is a combination of visual and performing arts, humanities, science and computing. Students are exposed to ideas and insights on media from communication theorists, programmers, educators, and technologists. The need to study new media is grounded in a basic idea: when the media through which we create and communicate shift from primarily analogue forms ( print, film, canvas, vinyl) to digital forms and networks, are practices of creating and communicating change along with them.

The field of media studies probes/ investigates into important burning issues and topics:

- Study of Cinema production and digital media

- Studies of topics to produce documentary movies

- Analysis of successful documentary movies

- Media studies

- History, criticism, design and philosophy of media

- Technical management of media

- Keen study of media with special focus on digital media

- Public Interaction and interviews

- Script and screen writing

- Trans Media and Digital Story Telling

Comparative Literature or global Literature deals with the literature of different cultures and languages. It is frequently practiced with masterpieces of different languages. It can also be practiced with works of same language from two different cultures and ethnicities. The field of comparative literature deals with literature as a whole and other parts of human culture, politics, history, science and sometimes even the sociology.

Media is an outlet tool that stores and provides information to its consumers. There are many faces of media like print media, digital media. Photography, advertising, cinema and broadcasting also come under it. The main intent of any media is to pass information to pubic. A common man when he wakes up in the morning either he looks for a newspaper or switches on the television to know what is happening around him or on the planet. Let's not ignore the existence of the latest form of media which is mobile phones and internet. A large number of consumers, nowadays, rely on internet to get news. Although ophthalmologist are constantly warning people to reduce the usage of mobile phones but still there are millions of people who switch on their mobile phones in the morning to look for the current news.

Print media typically includes newspapers, articles, journals etc. on the other hand, electronic media could be internet, television etc.

Print Media

- Print media is considered more authentic form of information than electronic media.

- Choice of reading - Printed material like newspapers and magazines can be carried easily.

- Its cost is not very high as compared to other kind of media. A daily newspaper is generally available for less than a dollar in most parts of the world.

- It is an handy kind of reference material. People who even work in the field or farms can carry it as a reference.

- In countries like India blue chip companies generally rely on newspapers for ad campaigns Electronic media

- Although electronic media is a modern and advance form of media but in some countries it has lost its credibility.

- Electronic media has created a lot of jobs for people and it is a more interesting form of media. People can see motion pictures of events and accidents. They can directly hear the opinions of people just in a way as they chit chat in their drawing rooms. Some TV channels even provide the opportunity of calling to their Politicians or showbiz personalities and asking their questions to the audience.

- There are hundreds of channel available. The viewers can watch the channels of their choice.

- For a newspaper you need to wait for it to come next day whereas a TV channel provides the news in minutes. The viewers can get live information of events.

Social networking sites are increasingly becoming important for expression of individual identity. The articulation is not merely narcissistic, but it also supports peer-based sociality. Young people use social networking sites to experiment as well as find political, ethnic, cultural or sexual identity. A research shows that social networking sites can facilitate a sense of connectedness, community and belonging. The opportunity to express one creatively, explore and experiment with identity and the production---as well as consumption---of online content is central to the way that social networking sites strengthens and builds communities.

The second line of argument is even more common to the common imagination that Journalism informs while literature interprets. The basic demarcation perhaps suffices to define the roles assigned to them but the danger of journalism looms large on the literary thought process. The passages written by Joyce, Hemingway and Stephan Crane 
remind of the lost journalistic connections between journalism and literature. When a journalist writes, he writes the events of the day and when a litterateur writes, he writes the thought of the day. The dimensions of literature and the objectives of journalism have a coalescence of the kind one is left gasping for breath itself, testifies the close yet marginal distinctions between the two. History records silently the literary complexities of a confused mind and the reports of a journo filed at the end of the day with its own judgment on either of the two as abiding or revolting. Culture is what both the pundits of literature and journalism study. The difference lies in the manner of treating its shades and colors.

\section{CONCLUSION}

The dimensions of literature breach boundaries to conform to the possibilities of generating discourses on issues of humanitarian and social concerns. Psychology and philosophy have given the edges to literature. Literature and journalism both study culture in their own ways. Academic definitions of both literature and journalism have overlapped time and again. Journalism is giving readers the information about what they want to know. Sometimes electronic media steps further ahead and gives information of what their audience even don't want to know. Hence many kinds of journals and newspapers like political journals, journals on movies and soaps, journals on fashion and vogue, journals on agriculture journals on social life, journals on crime and investigation, journals on religious believe and journals on pets. Sometimes we feel surprised about the types of journals but, I think, they produce what is being sold in the market. We can apply the same logic for the journals on pornography. They are being produce because they are being sold in the market. The answer of the producers of such journal to their critics might be 'stop the demand of such journals from market and we will stop producing them.' The logic of demand and supply should be applied here too. The writers of this paper find very difficult to classify the political journal or the journals tacitly owned by political parties. This can also be applied on TV news channels. Many news channels around the world have become the mouthpiece of political parties. In the countries like India, every channel is owned by one or other political party. The minute you switch on the TV you clearly understand the ownership of the channel. However, it cannot be ignored that there are some TV |Channels which are truly involved in objective journalism.

Culture is a common pursuit chased by the slogan shouting cultural critics like Edward Said, Gayatri Spivak, Antonio Gramsci, Roland Barthes, Jacques Derrida and Lacan. The journalism informs while literature interprets hence the danger of journalism looms large on the literary thought process. Journalists pen the events while the writers pen the thoughts. If a journalist does not pen the events honestly or objectively then this might have a lethal impact on society. This may create a chasm between societies. We have find many examples of such kind in the history. The same can be said about the literature. It is the responsibility of a creative writer to produce the true image of the society or point at the problems of the society objectively. History is developed on the basis of the events reported by journalists and on the basis of the events.

\section{REFERENCES}

[1] Anzaldua, Gloria. Borderlands/La Frontera. (1980). A New Meztiza. San Francisco:Spinsters/ Aunt Lute Book Company.

[2] Arendt, H. (2007). Reflections on literature and culture. (S. Young-ah Gottlieb, Ed.). Palo Alto, CA: Stanford University Press.

[3] Evans, Ifor. (1990). A Short History of English Literature. London, Penguin Group Wrights Lane London, England.

[4] Henderson, Mae G. Borders. (1995). Boundaries and Frames. New York: Routledge.

[5] Legouis and Cazamian. (1981). History of English Literature.(1924 Premiere edition Francaise) New Delhi, Macmillan Publishers India Ltd. New Delhi.

[6] Liang, L. \& Dole, J. (2006). Help with teaching reading comprehension: Comprehension instructional frameworks. The Reading Teacher, 59(8), 742-753.

[7] Thornley, C.C and Roberts, Gwyneth. (1991). An Outline of English Literature. London, Longman Group Limited, London (formerly Messers Longmans, Green \& Co. Ltd, London).

[8] Wahab, Siraj. (2014). Modern day Journalism and General Views Mumbai, Saket Publications.

Mohammed Osman did his PhD in Literature from Dr B A Marathwada University of India in Literature. He did his B A from Mumbai University and M A from Dr B A Marathwada University of India. He has been teaching English at King Khaled University for last seven years. He has been involved in teaching Grammar, Writing, and Reading. He is in charge King Khalid University department of Language and Translation Examination committee. He has interest in research in the field of linguistic, autobiographies and short stories in literature.

Mohammed Nurul Islam (Ph.D) is an assistant professor in the Department of English, Faculty of Languages and Translations, King Khalid University, Kingdom of Saudi Arabia Since 2009. His areas of interest include ELT, ESP and World Englishes. 
Nisar Ahmad Koka, being highly motivated in carrying out teaching and research in the field of linguistics, did his M.A. and Ph.D. in Theoretical and Sociolinguistics Linguistics from Aligarh Muslim University Aligarh, India in 1998 and 2002 respectively. He has been engaged in teaching linguistics /applied linguistics and English as a Foreign Language (EFL) in different universities/institutions for last 18 years or so. Dr. Koka has published more than half a dozen of research articles in different national and international journals, and has also presented several papers in various conferences/seminars covering various themes and topics concerning linguistics and language teaching. He has also co-authored 3 books on 'Testing and Evaluation' in Indian Languages while working as junior resource person on the projects of Multipurpose Indian Language Evaluation System (MILES) and National Testing Service (NTS) India. Dr. Koka is currently engaged as an assistant professor at the Department of English, Faculty of Languages and Translation, King Khalid University Abha, KSA teaching English as Foreign Language (EFL). 